IWONA DOROTA CZECHOWSKA

EDYTA RUTKOWSKA-TOMASZEWSKA

https://doi.org/10.33995/wu2021.2.2

\title{
Financial Ombudsman w Wielkiej Brytanii jako efektywny alternatywny system rozstrzygania sporów na rynku finansowym - lekcja dla Polski?
}

Instytucja rzecznika finansowego, szczególnie po kryzysie na rynku finansowym, stała się dodatkowym podmiotem infrastruktury instytucjonalnej ochrony klienta na rynku finansowym niezbędnym dla zwiększenia poziomu - mocno nadwyrężonego - zaufania konsumentów do rynku usług finansowych i organów jego ochrony ${ }^{1}$. Celem opracowania jest przedstawienie i ocena funkcjonowania Rzecznika Finansowego w Wielkiej Brytanii (Financial Ombudsman Services)². Brytyjski Rzecznik Finansowy jest największq takq instytucja na świecie, funkcjonuje od 2001 roku i ma już ugruntowana pozycję w systemie organów ochrony klienta na rynku finansowym w tym kraju. Pytanie badawcze, na które autorki poszukuja odpowiedzi, dotyczy rozstrzygnięcia kwestii, czy FOS jako alternatywny system rozwiqzywania sporów jest efektywny i czy jako taki może stanowić wzorzec dla tego typu instytucji w innych krajach, w szczególności - dla Polski ${ }^{3}$. Celem tego systemu jest zapewnienie konsumentowi ustawowego alternatywnego systemu rozstrzygania sporów (ADR), w ramach którego skargi na dostawców usług finansowych przede wszystkim przez indywidualnych klientów (konsumentów) mogq być szybko i przy zachowaniu minimum formalności rozstrzygane w wiqżacy sposób przez profesjonalny i niezależny podmiot (rzecznika) w sprawiedliwy i rozsqdny sposób. Wartykule zastosowano następujace metody badawcze: analizę aktów prawnych, desk research oraz analizę danych statystycznych FOS.

1. Por. Funkcjonowanie systemu ochrony praw klientów podmiotów rynku finansowego, Najwyższa Izba Kontroli, Warszawa 2014 r., Informacja o wynikach kontroli a P/13/038, https://www.nik.gov.pl/plik/id,6423,vp,8193.pdf [dostęp: 31.08.2021].

2. Dalej: FOS.

3. W tym miejscu autorki zastrzegaja, że artykuł niniejszy nie ma charakteru porównawczego. Nie chodzi w nim o porównanie Financial Ombudsman Services z Rzecznikiem Finansowym w Polsce, a jedynie o zasygnalizowanie pewnych rozwiązań przyjętych w Wielkiej Brytanii w ramach instytucji Rzecznika Finansowego, które warto byłoby rozważyć do zaimplementowania w Polsce. 
Słowa kluczowe: ADR, system rozstrzygania sporów, rzecznik finansowy, rynek finansowy.

\section{Wprowadzenie}

Rodzajem pozasądowego mechanizmu rozstrzygania sporów na rynku finansowym (ang. Alternative Dispute Resolution, dalej: ADR] w Europie Zachodniej jest instytucja rzecznika praw (ombudsman $]^{4}$. W Dobrych Praktykach Banku Światowego, dotyczących ochrony konsumentów na rynkach finansowych, zalecono, aby oprócz mechanizmów reklamacji ustanowić dostęp do: przystępnego cenowo, skutecznego, zaufanego, profesjonalnego i dysponującego możliwością wykorzystania mechanizmu rozstrzygania sporów, niezależnego rzecznika finansowego lub równoważnej instytucji, mającej zdolność do egzekwowania prawa ${ }^{5}$. Rzecznik finansowy, jako wyspecjalizowany organ ochrony klienta na rynku finansowym wyposażony w różnego typu kompetencje do podejmowania działań, zarówno w sprawach indywidualnych konsumentów, jak i tych o charakterze ogólnym (w tym także do alternatywnego rozstrzygania sporów klientów z instytucjami finansowymi], stał się podmiotem publicznym potrzebnym dla zwiększenia w rzeczywistości pokryzysowej zaufania do rynku usług finansowych ${ }^{6}$. Między poszczególnymi podmiotami tego typu widoczne są różnice, np. ponad połowa - 58\%, spośród 63 krajów objętych badaniem w 2011 roku - posiadało mechanizm rozstrzygania sporów przez stronę trzecia?, w 30\% z badanych krajów występował wyspecjalizowany rzecznik, a 21\% krajów działał rzecznik praw obywatelskich, który m.in. zajmował się ochroną konsumentów na rynku finansowym. Rzecznik finansowy występował w krajach o wysokich dochodach PKB (57\% badanej grupy), natomiast w krajach o dochodach niskich był obecny o wiele rzadziej (jedynie $5 \%$ badanej grupy) ${ }^{8}$. W innym badaniu, z roku 2014 wskazano, że na 114 krajów w 69 występuje instytucja rzecznika finansowego ${ }^{9}$. Jeśli chodzi o mechanizmy finansowania ADR, z przeprowadzonego w 2011 roku badania wynikało, że są one różne. W 33 krajach (z 63, dla których były dostępne dane) rzecznicy praw obywatelskich (ew. ośrodki mediacyjne) byli w pełni finansowani przez rząd, a w 22 krajach - przez stowarzyszenia branżowe lub członków (usługodawców). W 8 krajach rzecznikami praw obywatelskich były partnerstwa publiczno-prywatne, współfinansowane przez rząd i sektor prywatny ${ }^{10}$. W kolejnym badaniu, z roku 2017, analizowano występowanie podmiotów

4. Szerzej na ten temat w odniesieniu do UE i rozwiązań przyjętych w jej krajach zob. J. Mucha, Alternatywne metody rozwiqzywania sporów konsumenckich w Unii Europejskiej, CH Beck, Warszawa 2020; M. Bombin, Methods Used in Evaluating The Ombudsman Function of an International Organization, "JIOA" 2014, Vol. ?, s.10.

5. World Bank, Good Practices for Financial Consumer Protection, 2012, http://responsiblefinance.worldbank.org/ / media/GIAWB/FL/Documents/Misc/Good-practices-for-financial-consumerprotection.pdf [dostęp: 20.07.2021] .

6. Szerzej: E. Rutkowska-Tomaszewska, Zaufanie do rynku finansowego i instytucji finansowych jako przedmiot ochrony prawnej (kilka uwag na tle nadużyć instytucji finansowych wobec klientów), „Przedsiębiorczość i Zarządzanie" 2018, t. XIX, z..9, cz. II, s. 17-18.

7. O.P. Ardic, J. Ibrahim, , N. Mylenko, Consumer protection laws and regulations in deposit and loan services: A cross-country analysis with a new data set, "World Bank Policy Research Working Paper" 2011, nr 5536, s. 13.

8. Ibidem.

9. Global Survey on Consumer Protection and Financial Literacy: Oversight Frameworks and Practices in 114 countries. Report. Washington DC: The World Bank, 2014.

10. O.P. Ardic, J. Ibrahim, N. Mylenko, op. cit., s. 13. 
ADR w badanych krajach. Zauważono, że w 80 przypadkach, odpowiadających 65\% badanej grupy, występował ADR dedykowany dla konsumentów na rynkach finansowych, np. rzecznik finansowy. Częstość występowania ADR różniła w zależności od dochodu i określonej grupy regionalnej. Najczęściej ADR występował w jurysdykcjach o wysokim dochodzie oraz w Azji południowej, Azji Wschodniej i Europie oraz Azji Centralnej ${ }^{11}$.

Biorąc pod uwagę skalę aktywności (liczbę zgłoszeń przez konsumentów / klientów rynku finansowego na jakość usług], Financial Ombudsman Service funkcjonujacy w Wielkiej Brytanii jest największym rzecznikiem finansowym w Europie ${ }^{12}$ i na świecie ${ }^{13}$. Wielka Brytania była pierwszym krajem w Unii Europejskiej, w którym wprowadzono instytucję międzysektorowego rzecznika finansowego ${ }^{14}$, łącznie dla wszystkich sektorów rynku finansowego (dla całego rynku finansowego) ${ }^{15}$. Dostęp do bezpłatnego, niezależnego i cieszącego się zaufaniem konsumentów ${ }^{16}$ systemu rozstrzygania sporów z instytucjami finansowymi (dostawcami usług finansowych) w Wielkiej Brytanii ${ }^{17}$ stał się ważnym rozwiązaniem w ramach systemu ochrony konsumentów na rynku usług finansowych. FOS jest największą instytucją rozwiązującą spory na rynku finansowym w Wielkiej Brytanii ${ }^{18}$, gdzie alternatywne metody rozwiązywania sporów przez ombudsmana odgrywają istotną rolę i są niezwykle popularne ${ }^{19}$. To podmiot uprawniony do prowadzenia postępowań pozasądowych, zgodnie z dyrektywą ADR ${ }^{20}$, zatwierdzony przez Financial Conduct Authority ${ }^{21}$ (FCA).

11. World Bank, Global Financial Inclusion and Consumer Protection Survey, 2017 Report, s. 46, https://openknowledge. worldbank.org/bitstream/handle/10986/28998/122058.pdf? sequence=5\&isAllowed=y [dostęp: 18.08.2021].

12. D. Thomas, F. Frizon, Resolving disputes between consumers and financial businesses: Fundamentals for a financial ombudsman. A practical guide based on experience in western Europe, World Bank. Global Program on Consumer Protection and Financial Literacy, January 2012, http://documents1.worldbank.org/curated/en/301411468261335666/ pdf/699160v20ESWOPOI0OmbudsmenOVol20ECA.pdf [dostęp: 20.07.2021]; M. Yokoi-Arai, A comparative analysis of the financial ombudsman systems in the UK and Japan, "Journal of International Banking Regulations" 2004, nr 5[4], s. 333-357, https://doi.org/10.1057/palgrave.jbr.2340175 [dostęp: 20.07.2021].

13. B. Bradford, N. Creutzfeldt, Procedural justice in Alternative Dispute Resolution: Fairness judgments among users of Financial Ombudsman services in Germany and the United Kingdom, "Journal of European Consumer and Market Law" 2018, nr ? (5).

14. D. Thomas, F. Frizon, op. cit., s. 25.

15. Ibidem.

16. X. Huijuan, On Financial Ombudsman System in UK and Protection of Consumers'Rights and Interests - comment on our financial regulations, "Finance Forum" 2015, Vol. 1.

17. D. Thomas, F. Frizon, op. cit., s. 25.

18. S.F. Ali, A. Da Roza, Alternative dispute resolution design in financial markets - some more equal than others: Hong Kong's proposed financial dispute resolution center in the context of the experience in the United Kingdom, United States, Australia, and Singapore, "Pacific Rim Law \& Policy Journal” 2012, Vol. 21, No. 3, s. 485.

19. Department for Business, Energy \& Industrial Strategy, Resolving Consumer Disputes Alternative Dispute Resolution and the Court System Final Report, April 2018, https://assets.publishing.service.gov.uk/government/uploads/system/uploads/attachment_data/file/698442/Final__eport__Resolving consumer_disputes.pdf [dostęp: 21.07.2021].

20. Dyrektywa Parlamentu Europejskiego i Rady 2013/11/UE z dnia 21 maja 2013 r. w sprawie alternatywnych metod rozstrzygania sporów konsumenckich oraz zmiany rozporządzenia (WE) nr 2006/2004 i dyrektywy 2009/22/WE (Dz.U. L 165 z 18 czerwca 2013, s. 63).

21. Jest to organ nadzoru nad instytucjami finansowymi w Wielkiej Brytanii, gdzie prawie wszystkie czynności związane z usługami finansowymi muszą być przez ten organ autoryzowane. Financial Conduct Authority (FCA) prowadzi rejestr usług finansowych https://register.fca.org.uk/s/. Ma trzy zasadnicze cele operacyjne: ochrona konsumentów usług finansowych na terenie U.K.; zachowanie integralności brytyjskiego systemu 
Celem niniejszego opracowania jest przedstawienie i ocena funkcjonowania Rzecznika Finansowego w Wielkiej Brytanii - Financial Ombudsman Services (FOS) - jako alternatywnego mechanizmu rozstrzygania sporów na rynku finansowym. Autorki poszukują odpowiedzi na pytanie badawcze: czy FOS jest systemem organem efektywnym w ramach alternatywnego systemu rozwiązywania sporów i czy może stanowić wzorzec dla innych tego typu instytucji, w szczególności w Polsce? Wszakże od października 2015 roku w Polsce także funkcjonuje Rzecznik Finansowy jako wyspecjalizowany organ w instytucjonalnej sieci ochrony klienta na rynku finansowym ${ }^{22}$. Utworzenie tej jednostki było efektem zaleceń wynikających z raportu NIK z 8 kwietnia 2013 roku²3, dotyczącego funkcjonowania systemu ochrony praw klientów podmiotów rynku finansowego. Rzecznik Finansowy został powołany odrębną ustawą o charakterze ustrojowo-procesowym²4. Ustawa o rozpatrywaniu reklamacji przez podmioty rynku finansowego i o Rzeczniku Finansowym ${ }^{25}$ wprowadziła nie tylko jednolity system rozpatrywania reklamacji klientów na podmioty rynku finansowego, ale także instytucję Rzecznika Finansowego ${ }^{26}$. Natomiast od 1 stycznia 2016 roku $^{27}$ funkcjonuje przy Rzeczniku Finansowym także pozasądowe postępowanie w sprawie rozwiązywania sporów między klientem a podmiotem rynku finansowego ${ }^{28}$.

By zrealizować zamierzony cel badawczy, w niniejszym opracowaniu zastosowano następujące metody badawcze: analizę aktów prawnych, desk research i analizę danych statystycznych FOS.

finansowego, promowanie uczciwej konkurencji pomiędzy firmami świadczącymi usługi finansowe w interesie konsumentów. Z dniem 1 kwietnia 2013 r. FCA stała się odpowiedzialna za sprawowanie nadzoru nad wszystkimi regulowanymi firmami finansowymi oraz nadzoru ostrożnościowego nad firmami, które nie są nadzorowane przez Prudential Regulation Authority (PRA). Więcej informacji na temat FCA https://www. fca.org.uk/about/the-fca [dostęp: 3.09.2021].

22. Por. E. Rutkowska-Tomaszewska, Czy struktura instytucjonalna ochrony konsumenta na rynku usług finansowych wymaga zmian?, „Przegląd Ustawodawstwa Gospodarczego” 2019, nr 11, s. $15-23$.

23. Funkcjonowanie systemu ochrony praw klientów podmiotów rynku finansowego, Najwyższa Izba Kontroli, Warszawa 2014, Informacja o wynikach kontroli a P/13/038, https://www.nik.gov.pl/plik/id,6423,vp,8193.pdf [dostęp: 31.08.2021].

24. Por. E. Rutkowska-Tomaszewska, Current trends in consumer protection regulations in the financial services market in Poland, [w: Consumer rights protection: threats and opportunities for enhancing consumer awareness, [red.] S. Smyczek, Uniwersytet Ekonomiczny w Katowicach, Katowice 2020, s. $72-86$.

25. Ustawa z dnia 5 sierpnia 2015 r. o rozpatrywaniu reklamacji przez podmioty rynku finansowego i o Rzeczniku Finansowym (Dz. U. 2019, poz. 2279 z późn. zm.).

26. I.D. Czechowska, J. Stawska, R. Witczak, Bezpieczeństwo i stabilność systemu finansowego. Perspektywa makro-i mikroekonomiczna, Wydawnictwo Uniwersytetu Łódzkiego, Łódź 2020, s. 129.

27. Ustawa o rozpatrywaniu reklamacji przez podmioty rynku finansowego i o Rzeczniku Finansowym weszła w życie z dniem 11 października 2015 r., a przepisy rozdziału 4 (dotyczące pozasądowego postępowania w sprawie rozwiązywania sporów między klientem a podmiotem rynku finansowego) weszły w życie z dniem 1 stycznia $2016 \mathrm{r}$.

28. Szerzej: J. Kalak, Pozasqdowe postępowanie w sprawie rozwiqzywania sporów między klientem a podmiotem rynku finansowego, „ADR” 2016, nr 2, s. 26; K. Magoń, Ochrona klienta usług finansowych w świetle ustawy o rozpatrywaniu reklamacji przez podmioty rynku finansowego io Rzeczniku Finansowym - zagadnienia wybrane, [w:] Ochrona klienta na rynku usług finansowych w świetle aktualnych problemów i regulacji prawnych, [red.] E. Rutkowska-Tomaszewska, CH Beck, Warszawa 2017. 


\section{Deskrypcja FOS jako alternatywnego systemu rozwiązywania sporów (ADR)}

Financial Ombudsman Services (FOS) - Rzecznik Usług Finansowych - jest niezależnym organem publicznym. Został utworzony w 2001 roku przez brytyjski Parlament ustawą o usługach i rynkach finansowych z 2000 roku $^{29}$ (Financial Services and Markets Act - dalej FSMA), w celu rozstrzygania sporów konsumenckich na rynku finansowym w Wielkiej Brytanii, dotyczących detalicznych produktów finansowych (usług finansowych). Jego powołanie poprzedziła analiza potrzeb i doświadczeń rynku brytyjskiego, na którym działało wiele sektorowych instytucji, niewyposażonych w tak kompleksowe kompetencje jak FOS ${ }^{30}$. Do zakresu działania Financial Ombudsman Service (FOS) ${ }^{31}$ włączono osiem obszarów obsługiwanych poprzednio przez niezależnych rzeczników praw obywatelskich i systemów rozpatrywania skarg, w tym Rzecznika Ubezpieczonych, Rzecznika Inwestycji Osobistych, Urząd Reklamacji ds. Papierów Wartościowych i Kontraktów Terminowych, oraz Rzecznika Bankowego ${ }^{32}$.

Operatorem tego ustawowego systemu rozwiązywania sporów instytucji finansowych z konsumentami, zgodnie z art. 225 FSMA, jest spółka z „ograniczoną odpowiedzialnościa” - pod nazwa Financial Ombudsman Service Limited (dalej FOS LTD). Podstawa prawną działania FOS jest część XVI FSMA ${ }^{33}$ (Part XVI:) The Ombudsman Scheme (System Ombudsman) oraz załącznik nr $17^{34}$ do niej (Schedule 17). Poza tym, zasady jego funkcjonowania zostały określone przez organ nadzoru FCA w podręczniku tzw. Handbook ${ }^{35}$. Financial Conduct Authority (FCA), jako nadzorca i regulator branży usług finansowych, wydaje zasady, które określają, w jaki sposób FOS i instytucje finansowe powinny rozpatrywać skargi w Podręczniku FCA, w sekcji o nazwie Rozwiqzywanie sporów i skarg (DISP).

Uzasadnieniem alternatywnego sposobu dochodzenia roszczeń jest fakt, że w detalicznych usługach finansowych, zwłaszcza tych z udziałem osób o niskich dochodach, występuje znacząca nierównowaga sił między dostawcami a użytkownikami usług finansowych. Stąd też istotne jest funkcjonowania sprawnego, alternatywnego mechanizmu dochodzenia roszczeń w postaci najpierw skutecznej procedury przyjmowania i rozpatrywania skarg / reklamacji konsumentów / klientów, a następnie - w sytuacji gdy reklamacja nie zostanie rozwiązana w określonym terminie lub gdy klient nie jest zadowolony z rezultatów tego rozwiązania - skarga może być skierowana do niezależnego organu rozstrzygania sporów, w postaci rzecznika praw obywatelskich / finansowych lub prowadzącego usługi mediacyjne - mediatora ${ }^{36}$.

29. Financial Services and Markets Act 2000 UK Public General Acts 2000 c. 8, https://www.legislation.gov.uk/ ukpga/2000/8/part/ [dostęp: 30.06.2021].

30. Por. Ł. Szymański, Organizacja i działanie Financial Ombudsman Service w Wielkiej Brytanii. „Rozprawy Ubezpieczeniowe" 2008, nr 2, s. 135-142.

31. Ibidem.

32. S.F. Ali, A. Da Roza, op. cit., s. 499.

33. Art. 225 - 232 FSMA.

34. https://www.legislation.gov.uk/ukpga/2000/8/schedule/17 [dostęp: 3.09.2021].

35. Podręcznik organu nadzoru (FCA) dotyczący rozwiązywania sporów (FCA Handbook).Dispute resolution: Complaints, DISP-i, www.handbook.fca.org.uk n Release 1 I Nov 2020 https://www.handbook.fca.org.uk/ handbook/DISP/INTRO/?view=chapter [dostęp: 30.06.2021].

36. O.P. Ardic, J. Ibrahim., N. Mylenko, op. cit., s. 13. 
FOS stanowi alternatywny sposób rozstrzygnięcia sporu między konsumentem a instytucja finansowa, które z założenia ma być dość nieformalne i szybkie, zwłaszcza w porównaniu z postępowaniami sądowymi. Ważne jest, aby konsumenci mogli dochodzić roszczeń bez obaw lub ryzyka finansowego w ramach systemu FOS, a nie kosztownego i długotrwałego procesu sądowego. Alternatywa w postaci postępowania sądowego jest bardziej kosztowna i rozciągnięta w czasie, do tego stopnia, że wielu konsumentów prawdopodobnie wcale nie dochodziłoby swoich roszczeń, będących skutkiem nadużyć stosowanych przez instytucje finansowe. FOS ma przede wszystkim na celu ochronę konsumentów poprzez zapewnienie systemu ADR, który ma umożliwić im - oprócz uniknięcia kosztownych postępowań bezpośrednio przeciwko instytucjom finansowym - łagodzenie niektórych barier i uciążliwości w dochodzeniu roszczeń w ramach postępowań sądowych ${ }^{37}$.

FOS to nieformalna (niesformalizowana) i bezpłatna alternatywa dla postępowania sądowego. Skargi rozpatrywane są na podstawie tego, co FOS uważa za sprawiedliwe i rozsądne we wszystkich okolicznościach sprawy. Każda skarga, która wpływa do FOS, jest badana uczciwie, z zachowaniem transparencji i wysłuchania obu stron. Skargi nie muszą być zgłaszane osobiście, poszczególne sprawy są często rozpatrywane przez telefon, e-mail lub pocztę - w zależności od charakteru i kategorii skargi, jej przedmiotu i zakresu. Podmiot składający skargę nie potrzebuje profesjonalnego pełnomocnika, który będzie go reprezentował, możliwy jest kontakt z członkiem rodziny, przyjacielem lub inną osobą, która może wspomóc wnoszącego skargę do FOS. FOS podejmuje decyzje na podstawie faktów i dostępnych dowodów. Każda ze stron może przedstawić swoje stanowisko, pisemne dowody lub dokumenty ${ }^{38}$.

Rzecznik Finansowy jest niezależny w rozpatrywaniu sporu i podejmowaniu rozstrzygnięć, które opiera na przepisach prawa, zasadzie równości lub na wytycznych przyjętych w branży. FOS dokonuje rozstrzygnięć „na podstawie tego, co w opinii rzecznika (ombudsmana) odpowiada w danej sprawie kryteriom słuszności i rozsądku" (sekcja 228 FSMA). Orzecznictwo F0S ${ }^{39}$ ma istotne znaczenie praktyczne w zakresie stosowania przepisów także przez sądy ${ }^{40}$, gdyż modyfikuje wzajemne prawa i obowiązki stron umów o usługi finansowe na gruncie modelu common law ${ }^{41}$.

37. https://www.financial-ombudsman.org.uk/who-we-are/aims-values [dostęp: 25.07.2021].

38. https://www.financial-ombudsman.org.uk/consumers/how-to-complain [dostęp 27.07.2021].

39. http://www.financial-ombudsman.org.uk [dostęp 25.07.2021].

40. Szerzej, w szczególności w odniesieniu do obowiązku informacyjnego ubezpieczającego zob. P. Tereszkiewicz, Obowiqzek informacyjny ubezpieczajqcego i skutki jego naruszenia z perspektywy prawno-porównawczej: zmierzch uberrima fidei w epoce ochrony konsumenta?, [w:] Rozprawy cywilistyczne. Księga pamiqtkowa dedykowana Profesorowi Edwardowi Drozdowi, [red.] M. Pecyna, J. Pisuliński, M. Podrecka, LexisNexis, Warszawa 2013.

41. Szerzej na gruncie umów ubezpieczenia zob. P. Tereszkiewicz, op. cit. 


\section{Kompetencje Financial Ombudsman Service do rozpoznania skargi na podmiot nadzorowany oraz rozstrzygnięcia sporu}

Podmiotem właściwym do wniesienia skargi ${ }^{42}$ do FOS (skarżącym) jest: konsument ${ }^{43}$, małe i średnie przedsiębiorstwa (small businesses], organizacja charytatywna o rocznych dochodach poniżej 1 mln GBP lub powiernik funduszu powierniczego o wartości aktywów netto poniżej $1 \mathrm{mln} \mathrm{GBP}^{44}$, który korzysta, korzystałalbo rozważa możliwość korzystania z jakiejkolwiek usługi oferowanej przez podmiot podlegajacy nadzorowi FCA. Niektóre rodzaje podmiotów skarżących zostały wyraźnie wyłączone na mocy przepisów ${ }^{45}$. Regulacje dotyczące określenia, czy skarżący jest uprawniony do złożenia skargi, znajdują się w wydanym przez FCA Handbook DISP 2.?.

Zgodnie z art. 226 FSMA jurysdykcja obowiązkowa (przymusowa) FOS obejmuje skargi, które dotyczą działania lub zaniechania instytucji finansowych w wykonywaniu ich czynności, jeżeli są spełnione określone warunki:

a) skarżący chce (wnioskuje), by skarga została rozpatrzona w ramach programu;

b) pozwany jest podmiotem uprawnionym (podlega nadzorowi FCA) lub emitentem pieniadza elektronicznego w rozumieniu przepisów dotyczących pieniądza elektronicznego lub dostawcy usług płatniczych w czasie działania lub zaniechania, do którego odnosi się skarga;

c) działanie lub zaniechanie, którego dotyczy skarga, miało miejsce w czasie, gdy obowiązywały przepisy o jurysdykcji przymusowej w odniesieniu do danej działalności (objęte nadzorem FCA);

d) skarga dotyczy praktyki podmiotów regulowanych lub takich, które mogłyby być działaniami regulowanymi na podstawie sekcji 22 FSMA.

Zgodnie z art. 227 FSMA FOS może także rozstrzygać skargi w ramach jurysdykcji dobrowolnej określonej przez przepisy ustalone przez operatora systemu (FOS LTD) i zatwierdzone przez FCA, które dotyczą działania lub zaniechania osoby (pozwanego) w wykonywaniu czynności, do której mają zastosowanie zasady dobrowolnej jurysdykcji, jeżeli spełnione są warunki:

a) skarżący kwalifikuje się i wnioskuje, aby skarga ${ }^{46}$ została rozpatrzona w ramach programu;

b) w czasie działania lub zaniechania, do którego odnosi się skarga, pozwany (instytucja finansowa) uczestniczył w programie;

c) w momencie składania skargi w ramach programu strona pozwana nie wycofała się z programu zgodnie z jego przepisami;

42. Skarga jest rozumiana szeroko: jako ustne lub pisemne wyrażenie braku satysfakcji, zasadne bądź niezasadne, dotyczące świadczenia lub odmowy świadczenia usługi finansowej. Powinna zawierać informacje, że konsument poniósł (lub może ponieść) stratę finansową bądź uszczerbek majątkowy na skutek działalności instytucji finansowej (dostawcy usług finansowych).

43. Nie ma znaczenia fakt, czy miejscem zamieszkania konsumenta jest Wielka Brytania ani czy jest obywatelem brytyjskim. Istotne jest natomiast to, by podmiot, na którego skargę wnosi konsument, podlegał nadzorowi FCA.

44. DISP 2.7.3

45. DISP 2.7.9.

46. Jest to ustne lub pisemne wyrażenie braku satysfakcji, zasadne bądź niezasadne, dotyczące świadczenia lub odmowy świadczenia usługi finansowej. Powinna ona zawierać informacje pozwalające stwierdzić, że konsument poniósł (lub może ponieść) stratę finansową bądź uszczerbek majątkowy na skutek działalności instytucji finansowej (FSP - czyli dostawca usług finansowych). 
d) działanie lub zaniechanie, którego dotyczy skarga, miało miejsce w czasie, gdy w odniesieniu do danej działalności obowiązywały zasady dobrowolnej jurysdykcji; oraz

e) skarga nie może zostać rozpatrzona w ramach obowiązkowej jurysdykcji.

Obowiązkowa jurysdykcja FOS, stanowiąca większość rozpatrywanych spraw, obejmuje działania lub zaniechania regulowanych przez FCA dostawców usług finansowych (FSP) ${ }^{4 ?}$. Działalność, do której stosuje się jurysdykcja obowiązkowa FOS, to działalność regulowana ${ }^{48}$ (zob. sekcja 22 FSMA): usługi płatnicze, działalność w zakresie kredytów konsumenckich, udzielanie pożyczek pieniężnych zabezpieczonych hipoteką, udzielanie pożyczek pieniężnych, dokonywanie płatności przy użyciu karty, świadczenie pomocniczych usług bankowych lub wszelkie inne działania obejmujące doradztwo ${ }^{49}$. Składane skargi moga zatem dotyczyć: bankowości, ubezpieczeń (w tym Payment Protection Insurance ${ }^{50}$ - PPI), programów emerytalnych, szeroko rozumianych produktów lub usług oszczędnościowych i / lub inwestycyjnych, pożyczek, kredytów, kart kredytowych, usług świadczonych przez lombardy, usług pośrednictwa finansowego, papierów wartościowych (akcji, obligacji etc.). FOS jest właściwy w przypadku reklamacji dotyczących większości rodzajów produktów i usług finansowych świadczonych w Wielkiej Brytanii lub z Wielkiej Brytanii.

Jednym z założeń FOS jest nakłanianie podmiotów nadzorowanych do samodzielnego rozpatrywania skarg (reklamacji) konsumentów i rozwiązywania problemów związanych ze świadczonymi przez nie usługami i oferowanymi produktami finansowymi. Przed złożeniem wniosku o rozstrzygnięcie sporu przez FOS podmiot wnoszący skargę (zazwyczaj konsument), powinien zasadniczo wyczerpać postępowanie reklamacyjne w instytucji finansowej i uzyskać „ostateczne stanowisko" podmiotu, na który jest ona składana (dostawcy usług finansowych). FOS daży w pierwszej kolejności do rozstrzygnięcia skargi nieformalnie w drodze mediacji lub postępowania pojednawczego. Jeśli nie jest to możliwe, przechodzi ona na etap orzeczenia arbitra i wydania opinii, a jeśli strona jest niezadowolona z opinii arbitra, może zwrócić się do Rzecznika o dokonanie jej rewizji i podjęcie ostatecznej decyzji.

W ramach jurysdykcji zachowane jest dla skarżącego, który nie akceptuje decyzji FOS, prawo do wniesienia pozwu do sądu przeciwko FSP ${ }^{51}$. Do sądu z wnioskiem o kontrolę sądową może się zwrócić, w ciaggu trzech miesięcy, każda ze stron. Decyzje ombudsmana są zwykle wiążące dla przedsiębiorcy, ale nie sạ wiążące dla strony skarżącej ${ }^{52}$. W Wielkiej Brytanii obowiązuje „podstawowa zasada, zgodnie z która, z wyjątkiem najbardziej wyjątkowych okoliczności, jurysdykcja sądowa [kontrola sądowa] w odniesieniu do $\mathrm{FOS}^{53}$ nie będzie wykonywana w przypadku, gdy do-

47. DISP 2.3.

48. Pełna lista podmiotów znajduje się odpowiednio na stronach internetowych FCA https://www.fca.org.uk/firms/ authorisation/how-to-apply/activities [dostęp: 25.07.2021].

49. DISP 2.3.1.

50. Są to ubezpieczenia, które gwarantują wypłatę określonej w umowie kwoty, mającej pokryć spłatę części miesięcznych rat kredytów hipotecznych, pożyczek, zadłużenia na karcie kredytowej lub innych, określonych w umowie płatności w przypadku, gdy ubezpieczony nie będzie w stanie pracować.

51. Section 228(2) FSMA; DISP 3.6.4.

52. S.F. Ali, A. Da Roza, op. cit., s. 485. K. Gajda-Roszczynialska, Sprawy o ochronę indywidualnych interesów konsumentów w postępowaniu cywilnym, Wolters Kluwer, Warszawa 2011 [dostęp w wersji elektronicznej: 30.06.2021].

53. Szerzej na temat jej omówienia w świetle decyzji Collinsa J in R (Duff) przeciwko Służbie Rzecznika Praw Obywatelskich (Financial Ombudsman Service] [2006] EWHC 1704. Zob. Permission to Proceed and the Availability of an Alternative Remedy Julian Davis Barrister Judicial Review of the Financial Ombudsman Service [2010] JR. 
stępne były inne środki odwoławcze i nie zostały wykorzystane” („zasada alternatywnego środka odwoławczego"]. Decyzja Rzecznika jest wiążąca dla obu stron i ostateczna, jeżeli skarżący zaakceptuje ja w wyznaczonym terminie, ale ustawa nie usuwa żadnego istniejącego wcześniej prawa do pozwania przez konsumenta dostawcy usług finansowych (art. 228 ust. 5 i 6 FSMA). Zasadniczo od wskazanej decyzji, zaakceptowanej przez skarżącego (konsumenta), nie można odwołać się do sądu. Niemniej, FOS, jako organ publiczny, podlega ocenie sądowej. Każda strona może jednak w ciagu trzech miesięcy zwrócić się do sądu z wnioskiem o kontrolę sądową orzeczenia Rzecznika, jeżeli twierdzi, że nie zastosował się on do uczciwej procedury lub działał nieracjonalnie - w takim przypadku sąd odsyła sprawę do Rzecznika w celu ponownego rozpatrzenia.

Kontrola sądowa koncentruje się jednak na procesie, który doprowadził Rzecznika do podjęcia decyzji, a nie na faktach i dowodach samego sporu ${ }^{54}$. Kwestią rozpatrywana przez sąd w ramach wniosku o kontrolę sądową jest to, czy postępowanie przed Rzecznikiem było dotknięte podstawowymi błędami lub naruszeniem naturalnej sprawiedliwości, czy Rzecznik nie zastosował się do uczciwej procedury lub działał nieracjonalnie i czy w związku z tym FOS prawidłowo wykonywał swoją funkcję statutowa. Niewykonanie przez FOS swoich obowiązków ustawowych na korzyść konsumentów powinno być rozpatrywane, w interesie publicznym, jak również na korzyść jednostki, w postępowaniu przeciwko samej FOS, a nie przeciwko FSP.

Takie przypadki w praktyce zdarzają się niezmiernie rzadko i znane sa jedynie incydentalne sprawy przegrane przez FOS w wyniku odwołania się podmiotu rynku finansowego (instytucji finansowej], na którego złożono skarge ${ }^{55}$. Odnotowano także przypadki, kiedy rzecznik wydał decyzję zaakceptowana przez skarżącego, przyznającă odszkodowanie, a następnie okazało się, że decyzja rzecznika była błędna (odszkodowanie powinno być wyższe) ${ }^{56}$. Konsument nie musi akceptować ostatecznej decyzji rzecznika i może wycofać się z postępowania w ramach FOS na dowolnym etapie. W przypadku niezadowolenia z decyzji określonego rzecznika nie może odwołać się od niej do innego rzecznika. Decyzja rzecznika jest ostateczna i nie jest możliwe ponowne rozpatrzenie tej samej sprawy z powodu powagi rzeczy osądzonej. Po wydaniu decyzji rzecznik nie ma uprawnień do zmiany lub rewizji swojej decyzji, a jedynym sposobem na jej uchylenie jest unieważnienie tej decyzji przez sąd w drodze kontroli sądowej.

FOS różni się od instytucji klasycznego ombudsmana jako niezależnego organu podlegającego bezpośrednio parlamentowi. Odpowiada za swoje wydatki finansowe przed FCA, która mianuje członków Rady FOS. FCA (i Rada FOS) nie są upoważnione do ingerowania w wykonywanie przez rzecznika funkcji rozpatrywania skarg i orzekania, on zaś rozpatruje je w oparciu o to, co w jego opinii jest sprawiedliwe i rozsądne (art. 228 FSMA). Operacyjna autonomia FOS od FCA i jej szeroki mandat zwiększają uprawnienia rzecznika do rozstrzygania skarg, poza ogólnymi wymogami regulacyjnymi ${ }^{5}$.

54. Permission to Proceed and the Availability of an Alternative Remedy Julian Davis Barrister Judicial Review of the Financial Ombudsman Service [2010] JR. Artykuł dotyczy kontroli sądowej rozstrzygnięcia FOS dostępnych na stronie http://www.hmcourts-service. gov.uk/cms/1220.htm [dostęp: 30.07.2021].

55. Ibidem.

56. Ibidem.

57. S. Gilad, S. Accountability or expectations management? The role of the ombudsman in financial regulation. "Law \& Policy" 2008, №. 30(2), s. 227-253. S. Gilad, Exchange without capture: The UK financial ombudsman service's struggle for accepted domain, "Public Administration" 2008, No. 86 [4], s. 907-924. https:// doi.org/10.1111/j.1467-9299.2008.00713.x (30.07.2021). 
Rzecznicy FOS ${ }^{58}$ nie ograniczają się do wydawania zaleceń (opinii), jak funkcjonujący w ramach FOS arbitrzy. Mają oni formalne uprawnienia do żądania od instytucji finansowych odszkodowania dla skarżących i wydawania wiążących rozstrzygnięć w tym zakresie (wiążących decyzji orzeczeń]. Rzecznik musi powiadomić instytucję finansową, na którą została wniesiona skarga, o swojej decyzji i ostatecznym wyniku (akceptacji jej lub braku akceptacji przez konsumenta).

W przypadku jurysdykcji obowiązkowej, zgodnie z art. 229 FSMA, rzecznik może - gdy skarga została rozpatrzona w ramach systemu na korzyść skarżącego - podjąć rozstrzygnięcie obejmujące: a zasądzenie od pozwanego takiej kwoty, jaką rzecznik uzna za godziwą rekompensatę za stratę lub szkodę (ze względu na rodzaj objęty podsekcją: zasq̨dzenie pieniężne);

b) nakazanie pozwanemu podjęcia w stosunku do skarżącego innych dodatkowych działań, które uznał za słuszne i właściwe.

FOS przyznaje odszkodowania za straty finansowe i niefinansowe w postaci rekompensat pieniężnych ${ }^{59}$. W zależności od tego, kiedy sprawa została wniesiona do FOS, obowiązują różne limity ${ }^{60}$ : a) 355000 GBP za skargi przesłane 1 kwietnia 2020 roku lub później, dotyczące działań lub zaniechań firm w dniu 1 kwietnia 2019 roku lub później;

b) 350000 GBP za skargi przesłane w okresie od 1 kwietnia 2019 roku do 31 marca 2020 roku, dotyczace działań lub zaniechań firm w dniu 1 kwietnia 2019 roku lub po tej dacie;

c) $160000 \mathrm{GBP}$ za skargi dotyczące działań lub zaniechań firm przed 1 kwietnia 2019 roku, które zostaną skierowane do serwisu FOS po tej dacie.

FCA do celów obowiązkowej jurysdykcji może określić maksymalną kwotę, która może zostać uznana za sprawiedliwe odszkodowanie za szczególny rodzaj straty lub szkody, przy czym różne kwoty mogą być określone w odniesieniu do różnych rodzajów skarg.

\section{Zasady finansowania działalności Financial Ombudsman Service i koszty postępowania}

Priorytetowa zasada funkcjonowania FOS w zakresie jego finansowania wyraża się w tym, że dostęp do jego usług jest dla konsumentów bezpłatny, gdyż nie ponoszą oni opłat za wnoszenie skarg do FOS ${ }^{61}$. Koszty finansowania ponosza instytucje finansowe (dostawcy usług finansowych) podlegający nadzorowi FCA. Zgodnie z paragrafem 9 Załącznika 17 do FSMA FOS przyjmuje roczny

58. W FOS funkcjonuje zespół rzeczników wybieranych przez organ wewnętrzny FOS LTD - Radę Dyrektorów spośród osób o odpowiednich kwalifikacjach i doświadczeniu, odpowiedzialnych za rozpatrywanie indywidualnych skarg, zgodnie z paragrafami 4 i 5 załącznika 17 FSMA. Z szerokiego panelu rzeczników RD wybiera Głównego Rzecznika i Dyrektora Generalnego oraz innych Głównych Rzeczników dyrektorów właściwych (https://www.financial-ombudsman.org.uk/who-we-are/staff/ombudsmen [dostęp: 19.08.2021].

59. The role of the Financial Ombudsman Service in the UK redress landscape (prezentacja PDF) Caroline Wayman Principal Ombudsman and Legal Director Financial Ombudsman Service- https://www.lawscot.org.uk/ media/6424/ilg financialombudsmen_slides.pdf [dostęp: 30.06.2021].

60. https://www.financial-ombudsman.org.uk/consumers/expect/compensation [dostęp: 30.06.2021].

61. The Case Fee, Financial Ombudsman Service, http://www.financialombudsman.org.uk/faq/answers/research_a5.html [dostęp: 30.06.32021]. 
budżet, zatwierdzony przez FCA ${ }^{62}$, i jest finansowany z różnych źródeł, w tym przede wszystkim poprzez roczną opłatę uiszczaną przez wszystkie podmioty finansowe oraz opłaty za indywidualne i zbiorowe skargi czy opłaty dodatkowe. Wspomniana roczna opłata uiszczana jest z góry, natomiast opłaty dodatkowe - po zaistnieniu określonych sytuacji. Wysokość rocznej opłaty na rzecz FOS ustala nadzorca FCA, na podstawie oczekiwanej liczby spraw. Corocznie, po konsultacjach, określa kwotę, która ma być zebrana z każdego bloku / segmentu branżowego systemu finansowego. Jej wysokość jest ustalana na podstawie planowanych kosztów budżetowych FOS i liczby pracowników Biura Rzecznika, wymaganych do rozpatrzenia oczekiwanej / planowanej liczby skarg.

Szczegóły faktycznych, należnych opłat różnią się w kolejnych latach, w zależności od rocznego budżetu Rzecznika Finansowego. W każdym roku budżetowym FCA i FOS konsultują się w sprawie wysokości rocznego budżetu Rzecznika Usług Finansowych ${ }^{63}$. Dla celów wyliczenia opłaty ogólnej, w zależności od rodzaju działalności gospodarczej, którą prowadzi każda firma, zalicza się ja do jednego lub kilku bloków branżowych, określonych w FEES 5 Annex 1. W dokumencie tym zawarto zestaw stawek opłat dla każdego bloku / segmentu z branży finansowej. FCA ustala również minimalny poziom tych opłat. Firmy muszą zapłacić na rzecz FCA ogólną opłatę z tytułu kosztów prowadzenia obowiązkowej jurysdykcji Rzecznika Finansowego. Zgodnie z określonymi regulacjami uczestnicy systemu finansowego są zobowiązani także do zapłaty na rzecz FOS obliczonej na podobnej podstawie kwoty na poczet kosztów prowadzenia dobrowolnej jurysdykcji Rzecznika Finansowego. Ogólną opłatę / składkę roczną (general levy), w ramach przymusowej jurysdykcji oblicza się jako sumę dwóch pozycji podstawy taryfowej, mającej zastosowanie do firmy w danym roku oraz skalkulowaną kwotę płaconą w relacji do odpowiedniej branży finansowej na dany rok. Instytucja finansowa ma z tego tytułu obowiązki informacyjne. W celu prawidłowego obliczenia powyższych opłat musi dostarczyć do FCA oświadczenie o wielkości działalności w poprzednim roku (tzw. roczny dochód). Wysokość opłaty ogólnej może wynosić przykładowo: od 45 GBP rocznie w przypadku małej firmy, zajmującej się doradztwem finansowym, do $1 \mathrm{mln}$ GDP w przypadku dużego banku. Do wyliczania wysokości opłaty można korzystać z kalkulatora opłat, umieszczonego na stronie FCA ${ }^{64}$. Zazwyczaj wysokość tej opłaty jest naliczana proporcjonalnie do udziału w rynku. Instytucje finansowe uiszczają tę opłatę niezależnie od tego, czy do Rzecznika wpłynęły skargi na ich działalność, czy nie. W ramach tej składki wszystkim podmiotom przysługuje darmowe rozpatrzenie 25 spraw rocznie ${ }^{65}$. $0 \mathrm{~d} 26$. skargi i każdej następnej pobierana jest opłata w wysokości 750 funtów (od 1 kwietnia 2021 r. ${ }^{66}$. Jeśli sprawa wymaga zbadania, staje się sprawa podlegająca opłacie, niezależnie od wyniku ${ }^{6}$. Na rys. 1. przedstawiono źródła finansowania FOS

62. Ta część tekstu została opracowana na podstawie Fees Manual Chapter 5. Financial Ombudsman Service Funding Fees Manual 38 s.pdf (30.06.2021).

63. Our 2021/22 plans and budget Consultation. December 2020. Financial Ombudsman Service.https://www. financial-ombudsman.org.uk/files/290682/plans-and-budget-consultation-2021-22.pdf [dostęp: 30.06.2021] .

64. https://www.fca.org.uk/firms/calculate-your-annual-fee/fee-calculator [dostęp: 30.06.2021].

65. https://www.financial-ombudsman.org.uk/who-we-are/governance-funding [30.07.2021] oraz https://www. financial-ombudsman.org.uk/files/287580/Annual-Report-and-Accounts-for-the-year-ended-31-March-2020.pdf s. 47 [dostęp: 3.08.2021].

66. Financial Ombudsman Service, Our2021/22 plans and budget, https://www.financial-ombudsman.org.uk/ files/298949/plans-and-budget-2021-22.pdf s. 23 [dostęp: 3.08.2021].

67. https://www.financial-ombudsman.org.uk/businesses/resolving-complaint/case-fees [dostęp: 3.09.2021]. 
w latach 2020-2021. Z informacji tam zamieszczonych wynika, że w tym okresie w strukturze źródeł finansowania dominowały opłaty stałe pochodzące od grup biznesowych.

Rysunek 1. Źródła finansowania FSO 2020/21

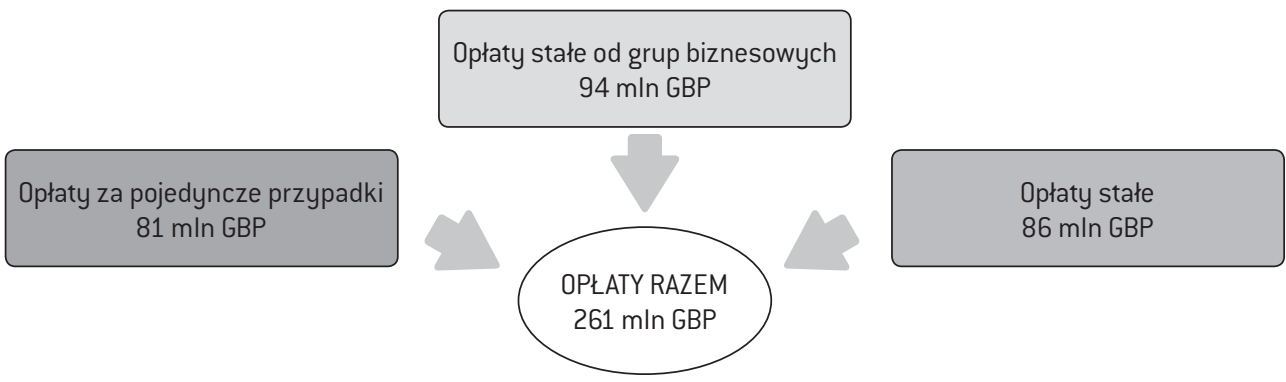

Źródło: opracowanie własne na podstawie FOS, Annual report and Accounts for the year ended, s. $55 \mathrm{https}: / / \mathrm{www}$. financial-ombudsman.org.uk/files/287580/Annual-Report-and-Accounts-for-the-year-ended-31-March-2020.pdf [dostęp: 3.08.2021].

Opłaty dokonywane przez największe, finansowe grupy biznesowe są wnoszone kwartalnie, z góry, na podstawie przewidywanej liczby skarg. Takie rozwiązanie jest bardziej efektywne od postępowania sądowego (a nie od rozwiązań przewidujących w sposób ryczałtowy i ujednolicony dla wszystkich podmiotów zobowiązanych do wnoszenia opłat), ponieważ obniża koszty administracyjne i zapewnia stabilny przepływ środków pieniężnych. Pod koniec roku następuje korekta, wyrównanie rozliczeń z tego tytułu ${ }^{68}$. Innymi źródłami finansowania działalności FOS są opłaty dodatkowe. Przykładem takiej opłaty jest ta, którą nalicza się za sprawy związaną z PPI ${ }^{69}$.

W odniesieniu do kosztów postępowania przewidziano rozwiązanie, którego celem jest zachęcenie do wnoszenia spraw do rozpatrzenia przez FOS, w przeciwieństwie do zasad obowiązujących w tym zakresie w typowym postępowaniu sądowym. Osoby składające skargę do FOS nie ponoszą odpowiedzialności za koszty prawne, jeżeli zostały one poniesione przez instytucje finansową, na którą wpłynęła skarga do FOS. Poza wyjątkowymi okolicznościami Rzecznik nie będzie wymagał od instytucji finansowej zwrotu kosztów poniesionych przez skarżącego, który korzysta z usług prawnika lub innego przedstawiciela. Podobna sytuacja ma miejsce w przypadku drobnych roszczeń (poniżej 5000 funtów) w sądach okręgowych. W odniesieniu do większych roszczeń stosuje się tzw. zasadę odszkodowania za koszty, zgodnie z którą stronie wygrywającej przyznaje się całość lub znacząca część poniesionych kosztów prawnych. Presja kosztów procesowych i ryzyko z tym związane, które często moga przekroczyć sumę sporu, są jednym z najpoważniejszych ograniczeń w prowadzeniu sporów sądowych i wpływają w istotnym stopniu na decyzje konsumentów dotyczące dochodzenia roszczeń na drodze postępowania sądowego. Wolny od tego ryzyka system dochodzenia roszczeń przed FOS niweluje tego typu obawy klientów. Jest to zatem

68. W systemie finansowym w Wielkiej Brytanii działaja grupy biznesowe takie jak np. Grupa Barclays, Grupa HSBC, Lloyds Banking Group, Grupa RBS/NatWest, Grupa Aviva, Nationwide Building Society Group, Grupa Santander. FEES 5 Annex 3R Case Fees Payable for 2020/21.

69. Instytucja Rzecznika Finansowego znacznie się rozwinęła w ciągu ostatniej dekady, właśnie z powodu roszczeń masowych, dotyczących PPI. Tego typu problemy wpłynęły na największą część finansowania. 
system, który zachęca zwłaszcza małe i średnie podmioty oferujące usługi i produkty finansowe (np. agenta ubezpieczeniowego, brokera) do rozpoznania skargi klientów we własnym zakresie i uniknięcia skierowania jej do FOS.

\section{Charakterystyka liczbowa działalności FOS}

FOS jest alternatywnym mechanizmem rozstrzygania sporów działającym zgodnie z dyrektywą ADR, w myśl której rozpatrywanie skarg powinno być realizowane na jak najwcześniejszym etapie, za pomocą takich środków jak: mediacja lub koncyliacja, czy postępowanie pojednawcze. Realizację tego założenia potwierdzają informacje liczbowe opisujące aktywność Financial Ombudsman Service w okresie 2018-2021 (tab. 1.).

Tabela 1. Roczne zestawienie skarg do FOS w latach 2018-2021

\begin{tabular}{|l|c|c|c|}
\hline \multicolumn{1}{|c|}{ Wyszczególnienie } & $2018 / 2019$ & $2019 / 2020$ & $2020 / 2021$ \\
\hline Liczba zgłoszonych zapytań konsumentów & 689110 & 642556 & 454259 \\
\hline Z czego liczba, która stała się nowymi skargami & 388392 & 271468 & 278033 \\
\hline Liczba rozpatrzonych skarg & 376352 & 295596 & 247916 \\
\hline Liczba skarg rozpatrzonych przez Rzecznika & 36954 & 29746 & 32243 \\
\hline Procent skarg rozwiązanych na rzecz klienta & $28 \%$ & $32 \%$ & $32 \%$ \\
\hline
\end{tabular}

Źródło: Financial Ombudsman Service. Annual review 2018/2019. Data in more depth $\mathrm{s} .12$ oraz annual-complainsdata-2019-20-exel i annual-complains-data-2020-21-exel [dostęp:30.07.2021].

Z informacji zamieszczonych w tab. 1. wynika, że w okresie 2018-2021 liczba zgłoszonych zapytań konsumentów zmniejszyła się, co można tłumaczyć konsekwencjami pandemii COVID-19. Liczba, która odpowiadała nowym skargom w latach 2019-2021, utrzymywała się na podobnym poziomie. Trzeba odnotować niewielką tendencję wzrostu skarg rozwiązanych na rzecz klienta. Podobne tendencje można odnotować w dłuższym okresie, o czym świadczą informacje liczbowe zamieszczone w tab. 2.

Tabela 2. Liczba skarg rozpatrzonych przez Rzecznika FOS w okresie 2014-2020

\begin{tabular}{|l|c|c|c|c|c|c|}
\hline \multicolumn{1}{|c|}{ Liczba } & $2014 / 2015$ & $2015 / 2016$ & $2016 / 2017$ & $2017 / 2018$ & $2018 / 2019$ & $2019 / 2020$ \\
\hline Skargi rozpatrzone & 448387 & 438802 & 336381 & 400658 & 376352 & 295596 \\
\hline $\begin{array}{l}\text { Rozstrzygniecie } \\
\text { ostateczną decyzja FOS }\end{array}$ & 43185 & 39872 & 38619 & 32780 & 36954 & 29746 \\
\hline
\end{tabular}

Źródło: Financial Ombudsman Service. Annual review 2018/2019. Data in more depth s. 12 oraz annual-complaintsdata-2019-20-exel i annual-complaints-data-2020-21-exel [dostęp: 3.09.2021].

Analizując informacje zamieszczone w tab. 2., można zauważyć, że różnica między liczba skarg rozpatrzonych a liczbą rozstrzygnięć dokonanych ostateczną decyzją Rzecznika wynika z faktu, że część z nich została wycofana przez konsumentów, część skarg została rozwiązanych nieformalnie przez śledczych lub arbitrów, część rozwiązano w procesie mediacji lub w ogóle nie 
należały do właściwości FOS. Wśród powodów odmowy rozpatrzenia skarg przez FOS wskazywano takie jak np. ${ }^{70}$

a) skarga jest nieuzasadniona;

b) przedmiot reklamacji został rozwiązany albo jest rozpatrywany przez inny podmiot;

c) sąd wydał merytoryczną decyzję;

d) sprawa jest w sadzie;

e) sprawa wiąże się z wysokimi kosztami pożyczkodawcy;

f) konsument zgodził się na skierowanie do innego podmiotu ADR;

g) konsument nie dostarczył żądanych informacji albo nie przestrzegał określonych terminów.

W 2001 roku - pierwszym roku funkcjonowania analizowanej instytucji - do FOS wpłynęło 25 tys. skarg, a w 2020 roku liczba wpływających skarg przekroczyła 1680 tys. Wzrost ten wynikał z różnych powodów, m.in. był konsekwencją skandali finansowych, ale także wynikiem dużego zaufania klientów do systemu FOS. Skargi składali zazwyczaj konsumenci, o wysokim statusie. Maksymalna kwota odszkodowania, którą mógł przyznać FOS, wyniosła 100000 GBP. Decyzje podejmowane przez FOS są uporządkowane w ramach tzw. bazy decyzji (ang. database of decisions) i umieszczane na stronie Rzecznika ${ }^{71}$. Liczbowe informacje na temat aktywności FOS przedstawiono w tab. 3.i tab. 4.

Tabela 3. Liczba, forma nowych zgłoszeń / zapytań / skarg, odszkodowania za straty niefinansowe, okres rozpatrywania skarg

\begin{tabular}{|c|c|c|c|c|c|}
\hline Okres & Telefon & $\begin{array}{c}\text { Pisemna } \\
\text { [także email] }\end{array}$ & Razem & $\begin{array}{c}\text { \% skargz odszkodowaniem } \\
\text { za straty niefinansowe }\end{array}$ & $\begin{array}{c}\text { Okres rozpatrywania } \\
\text { do 3 miesięcy [\%] }\end{array}$ \\
\hline $2018 / 2019$ & 633261 & 1047133 & 1680394 & 9 & 60 \\
\hline $2017 / 2018$ & 624769 & 831627 & 1456396 & 9 & 50 \\
\hline $2016 / 2017$ & 604278 & 790101 & 1394379 & 16 & 65 \\
\hline $2015 / 2016$ & 806171 & 825784 & 1631955 & 13 & 38 \\
\hline $2014 / 2015$ & 927737 & 859236 & 1786973 & 11 & 23 \\
\hline $2013 / 2014$ & 1150002 & 1207372 & 2357374 & 9 & 25 \\
\hline
\end{tabular}

Źródło: Financial Ombudsman Service. Annual review 2018/2019, s. 3, 16. Financial Ombudsman Service. Annual review 2017/2018,Fairnessin a changing world, s. 48, 57, 60.

Tabela 4. Liczba i przedmiot nowych skarg

\begin{tabular}{|l|c|c|c|c|c|}
\hline Wyszczególnienie & $\begin{array}{c}\text { Bankowość } \\
\text { i kredyty }\end{array}$ & $\begin{array}{c}\text { Inwestycje } \\
\text { i emerytury }\end{array}$ & $\begin{array}{c}\text { Ubezpieczenia } \\
\text { (bez PPI] }\end{array}$ & $\begin{array}{c}\text { PPI } \\
\text { Payment Protection } \\
\text { Insurance }\end{array}$ & $\begin{array}{c}\text { Razem } \\
\text { nowych } \\
\text { wniosków }\end{array}$ \\
\hline $2019 / 2020$ & $50 \%[103070)$ & $29 \%[10920]$ & $30 \%[32637]$ & $17 \%[122153]$ & 271468 \\
\hline $2018 / 2019$ & $39 \%[149933]$ & $4 \%[15606]$ & $11 \%[42346]$ & $46 \%[180507]$ & 388392 \\
\hline $2017 / 2018$ & $31 \%[104214]$ & $4 \%[12632]$ & $11 \%[36703]$ & $55 \%[186418]$ & 339967 \\
\hline $2016 / 2017$ & $31 \%[99888]$ & $4 \%[14471]$ & $12 \%[38155]$ & $53 \%[168769]$ & 321283 \\
\hline $2015 / 2016$ & $31 \%[10632])$ & $4 \%[14576]$ & $9 \%[31284]$ & $56 \%[188712]$ & 340899 \\
\hline
\end{tabular}

Źródło: Financial Ombudsman Service. Annual review 2018/2019. Data in more depth s. 5.

70. https://www.financial-ombudsman.org.uk/consumers/expect/who-we-can-help [dostęp: 25.07.2021].

71. https://www.financial-ombudsman.org.uk/decisions-case-studies/ombudsman-decisions [dostęp: 25.07.2021]. 
Analizy danych statystycznych publikowanych przez FOS w sprawozdaniach ${ }^{72}$, w przeglądzie tematycznym ${ }^{23}$, wskazuja, że od kilku lat głównym problem na brytyjskim rynku usług finansowych zgłaszanym przez konsumentów są ubezpieczenia kredytów (Payment Protection Insurance - PPI), które generują dużą liczbę sporów od lat 90. XX wieku4. Liczba skarg dotyczących tych produktów była relatywnie wobec innych wysoka. Skargi konsumentów na PPI były związane z wysokimi kosztami ubezpieczenia (od 20 do 50\% kosztów kredytu), szerokim katalogiem włączeń powodujących iluzoryczność ubezpieczenia, nieprawidłowościami na etapie sprzedaży ubezpieczenia (misselling) czy też długotrwała procedurą likwidacji świadczeń75. Równie często wskazywanym przedmiotem skarg konsumentów były produkty bankowe, a zwłaszcza kredyty. Przedstawione powyżej informacje liczbowe ilustrujące funkcjonowanie FOS wskazują na dużą efektywność działania tego podmiotu. Świadczy o tym wysoka, systematycznie rosnąca liczba składanych skarg, również w przeliczeniu na liczbę mieszkańców Wielkiej Brytanii. Tak wysoka liczba skarg może świadczyć o zaufaniu konsumentów i klientów rynków finansowych do tego systemu.

Analiza przypadków z praktyki FOS w zakresie rozstrzygania sporów z konsumentami usług finansowych instytucjami finansowymi (podmiotami, na które wnoszono skargi) wskazuje, że interakcja FOS z nimi oscylowała pomiędzy nieformalnym pojednaniem w ramach współpracy a znormalizowanym określaniem skarg na zasadzie kontradyktoryjności. Instytucje finansowe sprzeciwiały się nieformalnemu postępowaniu pojednawczemu, gdy chodziło o to, że ich zgoda na zadośćuczynienie indywidualnemu skarżącemu (klientowi, który wniósł skargę na załatwienie reklamacji przez instytucje finansową do FOS] może być interpretowana przez regulatora (FCA) lub media jako pociągająca za soba przyznanie odszkodowania dużej liczbie innych klientów w podobnych okolicznościach. Podobnie Rzecznik skłaniał się ku kontradyktoryjnemu, opartemu na precedensach podejściu do skarg w obliczu zewnętrznych zagrożeń dla jego autonomii i reputa-

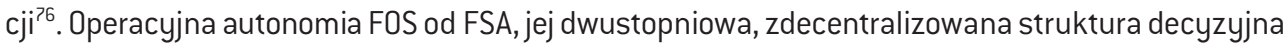
i etos organizacji uprzywilejowanego podmiotu zajmującego się rozpatrywaniem skarg, przestrzeganie indywidualnego rozstrzygania sporu (postrzeganego jako „jednorazowy”) - wszystko to

72. Roczne sprawozdanie z działalności (PDF) są publikowane na stronie i zawierają dane o tym, ile skarg otrzymaliśmy i jak długo trwa ich rozpatrywanie, np. Annual Activity Report 2019/2020: https://www.financial-ombudsman.org.uk/files/280886/ADR-activity-report-2019-20.pdf; Annual Activity Report 2018/2019: https://www. financial-ombudsman.org.uk/files/241933/ADR-activity-report-2018-19.pdf; Annual Activity Report 2017/2018: https://www.financial-ombudsman.org.uk/files/1955/ADR-activity-report-2017-18.pdf; Annual Activity Report 2016/2017: https://www.financial-ombudsman.org.uk/files/1954/ADR-activity-report-2016-17.pdf; Annual Activity Report 2015/2016: https://www.financial-ombudsman.org.uk/files/1953/ADR-activity-report-2015-16.pdf [dostęp: 30.06.2021].

73. Przegląd tematyczne skarg publikuje FCA. Patrz np. https://www.fca.org.uk/publication/thematic-reviews/ tr14-18.pdf; https://www.fca.org.uk/publication/thematic-reviews/tr15-01.pdf [dostęp: 30.06.2021].

74. Kompleksowo w literaturze polskiej na temat ubezpieczeń PPI zob. m.in. M. Więcko-Tułowiecka, Ochrona konsumentów w umowach ubezpieczenia, LexisNexis Warszawa 2014.

75. P. Pisarewicz, Analiza złych praktyk brytyjskich instytucji finansowych - wnioski dla rynku polskiego, „Zarządzanie i Finanse" 2014, nr 2, s. 33.

76. Szerzej na temat interakcji pomiędzy FOS i podmiotami rynku finansowego oraz ich wyborów pomiędzy strategiami współpracy, mediacji i kontradyktoryjnymi zob. Juggling Conflicting Demands: The Case of the UK Financial Ombudsman Service Sharon Gilad King's College London, doi:10.1093/jopart/mun008 April 8,

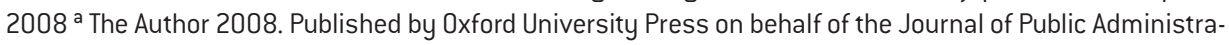
tion Research and Theory. 
zachęcało do współpracy instytucje finansowe w ramach nieformalnego postępowania pojednawczego. Jednocześnie powodowało, że spora część skarg była rozstrzygana nieformalnie przez arbitrów bez odwoływania się do formalnych decyzji rzeczników?

0 tym, że FOS może stanowić wzorzec do naśladowania dla Rzecznika Finansowego w Polsce, świadczy także fakt, że instytucja Rzecznika Finansowego w Wielkiej Brytanii wciąż się rozwija. Oferuje usługi nie tylko konsumentom, ale także małym firmom, a jej finansowa działalność jest oceniana przez niezależnego audytora. Ponadto co roku FOS konsultuje ze środowiskiem plany strategiczne oraz budżet. FOS reaguje bieżąco na wydarzenia z rynku finansowego i w gospodarki, czego egzemplifikacja jest rozpatrywanie reklamacji związanych z wpływem pandemii Covid-19 na problemy finansowe klientów.

\section{Podsumowanie, wnioski i rekomendacje dla Polski}

Po kryzysie na rynku finansowym skala nadużyć wobec konsumentów bardzo wzrosła, co było zauważalne w wielu krajach, także w Wielkiej Brytanii i w Polsce. Spowodowało to wzrost zapotrzebowania na skuteczne mechanizmy rozpatrywania sporów między instytucjami finansowymi a konsumentami.

Analiza kompetencji i zasad funkcjonowania FOS, na podstawie regulacji prawnych obowiązujacych w tym zakresie, jak i sprawozdań z działalności Rzecznika, pozwala na stwierdzenie, że ten brytyjski model jest popularnym alternatywnym sposobem rozstrzygania sporów z instytucjami finansowymi, zgodnym z dyrektywą ADR. Ma charakter quasi-regulacyjny i rozstrzyga sprawy przy użyciu sprawiedliwego i rozsqdnego standardu, przy jednoczesnej współpracy z organem nadzoru (FCA) i z zachowaniem niezależności.

Na uwagę zasługuje to, że FOS jest instytucją, która w sposób kompleksowy zajmuje się sprawami konsumentów: w zależności od potrzeby udziela kompleksowej informacji albo rozstrzyga szybko, skutecznie i rzetelnie powstały spór ${ }^{78}$. I co najważniejsze - w wiążący sposób. Przede wszystkim zaś wspiera interesy słabszych stron umów o usługi finansowe - konsumentów. Niemniej oprócz wielu pozytywnych ocen jakości działania FOS w literaturze przedmiotu oraz w praktyce pojawiaja się również poglądy krytyczne. Według nich FOS powinien większą uwagę przykładać do działań prewencyjnych ${ }^{\text {?9 }}$. Jeśli chodzi o finansowanie jego działalności, to struktura opłat dla Rzecznika nie uwzględnia ryzyka wynikającego z niesprawiedliwego traktowania konsumentów przez poszczególne instytucje finansowe (ryzyko zgodności). Takie rozwiązanie, różnicujące poziom opłat w zależności od liczby i ciężaru merytorycznego skarg, silniej motywuje instytucje finansowe do zmiany praktyk

\section{Ibidem.}

78. Judicial Review of the Financial Ombudsman Service: Permission to Proceed and the Availability of an Alternative Remedy, Julian Davis, s. 263-266, https://doi.org/10.5235/108546810793129358 [dostęp: 3.09.2021]; Collective Forms of Consumer Redress: Financial Ombudsman Service Case Study, Vicki Waye, Vince Morabito, s. 1-31, https://doi.org/10.5235/147359712800129902 [dostęp: 3.09.2021]; I. MacNeil, Consumer dispute resolution in the UK financial sector: the experience of the Financial Ombudsman Service, s. 515-524, https:// doi.org/10.1080/17521440.2007.11427928 [dostęp: 3.09.2021].

79. Około 30\% zgłoszeń nie przekształca się w sprawę formalną. R. Lloyd, Report of the Independent Review of the Financial Ombudsman Service, July 2018, s. 26. File:///C:/Users/user/AppData/Local/Temp/independent-review-2018.PDF [dostęp: 30.06.2021]. 
rynkowych wobec klientów ${ }^{80}$ na bardziej etyczne i zgodne z prawem oraz przede wszystkim zachęca do samodzielnego, skutecznego rozstrzygnięcia skargi klienta przez podmiot rynku finansowego.

Efektywny i skuteczny alternatywny system dochodzenia roszczeń i rozpatrywania sporów konsumentów z instytucjami finansowymi w Wielkiej Brytanii wpływa pozytywnie na kształtowanie kultury prawnej, poszanowania praw konsumentów usług finansowych i akceptacji poddawania się orzeczeniom FOS przez instytucje finansowe. Sprzyja temu wiążący co o zasady charakter orzeczeń wydawanych przez rzeczników w ramach FOS, a także zasady finansowania tej instytucji i „zachęty” stworzone w obszarze ponoszenia kosztów działania FOS, by skutecznie i efektywnie rozstrzygały one skargi klientów w ramach postępowań reklamacyjnych.

Wiążący charakter orzeczeń Rzecznika i ograniczone możliwości jego podważenia (w większości przypadków jego decyzje są podtrzymywane przez sądy), a także brak opłacalności dla instytucji finansowych do uruchamiania postępowań sądowych (o wiele bardziej dla nich kosztownych), powoduje, że brytyjski system pozasądowego modelu rozstrzygania sporów jest skuteczny.

Analiza systemu rozpatrywania przez FOS sporów dotyczących detalicznych produktów finansowych stanowi swoistego rodzaju połączenie trzech funkcji: typowej roli ombudsmana, organu ds. usług finansowych i funkcji orzeczniczej (sądów cywilnych). Wpisuje się to w pokryzysowe tendencje dotyczące postrzegania organów publicznych i roli państwa w zapewnieniu wysokiego i skutecznego poziomu ochrony konsumenta i egzekwowania prawa konsumenckiego i praw konsumenta nim gwarantowanych ${ }^{81}$. Prowadzić to ma do zwiększenia zaufania konsumentów do rynku finansowego i infrastruktury jego bezpieczeństwa, a dla podmiotów rynku finansowego jest podstawą do kształtowania właściwych praktyk rynkowych i wyciagania wniosków, co do sposobu rozstrzygania reklamacji klientów. Instytucja FOS odgrywa dużą rolę w zapewnianiu konsumentom szybkich i skutecznych metod rozwiązywania sporów i dochodzenia roszczeń wynikających z nadużyć wobec konsumentów podmiotów rynku finansowego objętych nadzorem

80. Ibidem.

81. Por. m.in. Komunikat Komisji do Parlamentu Europejskiego, Rady, Komitetu Ekonomiczno-Społecznego i Komitetu Regionów „Europejski program na rzecz konsumentów - wzmacnianie zaufania i wzrostu” COM/2012/0225 final (https://eur-lex.europa.eu/legal-content/EN/TXT/?uri=COM:2012:0225:FIN), a także Komunikat Komisji do Parlamentu Europejskiego i Rady „Nowy program na rzecz konsumentów. Poprawa odporności konsumentów na potrzeby trwałej odbudowy", Bruksela, dnia 13.11.2020 r. COM(2020) 696 final (https://eur-lex. europa.eu/legal-content/PL/TXT/PDF/?uri=CELEX:52020DC0696\&from=PL). Zob. także Rozporządzenie Parlamentu Europejskiego i Rady (UE) 2017/2394 z dnia 12 grudnia 2017 r. w sprawie współpracy między organami krajowymi odpowiedzialnymi za egzekwowanie przepisów prawa w zakresie ochrony konsumentów i uchylające rozporządzenie (WE) nr 2006/2004 (Dz.U. L 345 z 27 grudnia 2017, s. 1-26). Poza tym są one także widoczne w „Nowym Ładzie dla konsumentów” (Komunikat Komisji do Parlamentu Europejskiego, Rady i Europejskiego Komitetu Ekonomiczno-Społecznego z dnia 11 kwietnia 2018 r., COM(2018)183 final), https:// eur-lex.europa.eu/legal-content/pl/ALL/?uri=COM\%3A2018\%3A0183\%3AFIN], którego celem było wzmocnienie egzekwowania unijnego prawa konsumenckiego w świetle rosnącego ryzyka naruszeń w całej UE oraz unowocześnienie unijnych zasad ochrony konsumentów. W jego ramach i następstwie przyjęto następujace akty prawa unijnego dyrektywę (UE) 2019/2161 w sprawie lepszego egzekwowania i unowocześnienia unijnych przepisów dotyczących ochrony konsumenta; dyrektywę 2020/1828 z dnia 25 listopada 2020 r. w sprawie powództw przedstawicielskich wytaczanych w celu ochrony zbiorowych interesów konsumentów i uchylająca dyrektywę 2009/22/WE (Dz.U. L 409 z 4 grudnia 2020, str. 1-27); dyrektywę 2019/2161 z dnia 27 listopada 2019 r. zmieniającą dyrektywę Rady 93/13/EWG i dyrektywy Parlamentu Europejskiego i Rady 98/6/WE, 2005/29/WE oraz 2011/83/UE w odniesieniu do lepszego egzekwowania i unowocześnienia unijnych przepisów dotyczących ochrony konsumenta (Dz.U. L 328 z 18 grudnia 2019, str. 7-28). 
$F_{C A}^{82}$. System rozpatrywania sporów przez FOS z zachowaniem jego niezależności orzeczniczej od organu nadzoru (FCA), a jednocześnie ścisłej współpracy z tym podmiotem zapewnia kształtowanie prawidłowej praktyki rynkowej. Rozwiązania przyjęte w Wielkiej Brytanii w zakresie alternatywnego do sądowego systemu dochodzenia roszczeń konsumentów w sporach z instytucjami finansowymi, mogłyby być rozważone do wykorzystania w odpowiednim i możliwym zakresie przez inne państwa, w tym także Polskę.

Nie wszystkie rozwiązania są możliwe do przeniesienia wprost, a niektóre z nich wymagałyby także koniecznych zmian w polskim porządku prawnym. Wprawdzie z uwagi na to, że w niniejszym opracowaniu instytucja Rzecznika Finansowego funkcjonującego w Polsce nie była szerzej omawiana, trudno dokonać porównania obu tych instytucji, niemniej na uwagę zasługują niektóre rozwiązania przyjęte w tym zakresie w Wielkiej Brytanii. Między innymi godne rozważenia wydaje się zorganizowanie Biura Rzecznika Finansowego jako osoby prawnej na czele z Rzecznikiem Finansowym w randze ministra (na wzór aktualnego kształtu i statusu Urzędu Komisji Nadzoru Finansowego (art. 3 u.n.r.f. ${ }^{83}$ ]. Poza tym pożądane byłoby wprowadzenie zespołu rzeczników w tym Biurze powołanych do rozstrzygania sporów z zapewnieniem wysokiego ich poziomu merytorycznego i profesjonalizmu poprzez określenie wysokich kryteriów wymaganych na to stanowisko. Warto rozważyć także wprowadzenie wiążącego charakteru rozstrzygnięć rzeczników (zespołu rzeczników], przynajmniej w pewnym i ograniczonym zakresie, z zagwarantowaną możliwością zaskarżania ich decyzji do sądu w ściśle wskazanych (lecz nie każdych) okolicznościach, np. gdy doszło do rażącego naruszenia prawa (przesłanki skarg nadzwyczajnych), z jednoczesnym ustaleniem limitu kwot, do którego mogą oni orzekać. Ciekawym rozwiązaniem w ramach systemu FOS, które warto byłoby implementować w Polsce, jest finansowanie funkcjonowania Rzecznika Finansowego. Można byłoby - oprócz kwoty ryczałtowej wspólnej dla wszystkich podmiotów rynku finansowego - wprowadzić dodatkowe opłaty, uzależnione od liczby skarg na reklamacje rozstrzygnięte przez daną instytucję finansowa. Wydaje się, że taki zabieg mógłby skłaniać podmioty rynku finansowego do samodzielnego załatwiania skarg konsumentów w ramach postępowań reklamacyjnych.

W świetle obecnych tendencji regulacyjnych dotyczących rynku usług finansowych jest niezwykle ważne, by prawa i interesy konsumentów były odpowiednio chronione i egzekwowane. Przysłuży się to zwiększeniu i utrzymaniu zaufania konsumentów do rynku finansowego, ale także zagwarantowaniu jego długoterminowego i stabilnego rozwoju. Dużą rolę w tym obszarze odgrywają także wyspecjalizowane organy, kompetentne także w sprawach alternatywnych metod rozstrzygania sporów z instytucjami finansowymi. Pożądane jest wzmocnienie instytucjonalnej ochrony nieprofesjonalnych uczestników rynku finansowego w kierunku stworzenia spójnego i komplementarnego z sądowym systemu dochodzenia roszczeń i rozpatrywania konsumenckich sporów na rynku finansowym ${ }^{84}$.

82. Zob. przypis 78 i przywołana tam literatura.

83. Ustawa z dnia 21 lipca 2006 r. o nadzorze nad rynkiem finansowym (tekst jedn. Dz. U. 2020, poz. 2059 z późn. zm.).

84. Por. E. Rutkowska-Tomaszewska, Prawo ochrony konsumenta usług finansowych w świetle założenia racjonalnego ustawodawcy: kilka wybranych uwag, „Acta Universitatis Wratislaviensis. Przegląd Prawa i Administracji" 2020, nr 120/2, s. 481-498. 
Zwłaszcza teraz, w obliczu silnych tendencji w kierunku likwidacji instytucji Rzecznika Finansowego w Polsce ${ }^{85}$, konieczne jest nie tylko jego utrzymanie, ale także wzmocnienie kompetencyjne w odniesieniu do alternatywnego rozstrzygania sporów na rynku finansowym.

Wydaje się, że należałoby wprowadzić instytucje rzeczników w ramach Biura Rzecznika Finansowego, z zachowaniem roli Rzecznika Finansowego jako dyrektora naczelnego ustawowego alternatywnego systemu rozpatrywania sporów konsumentów z podmiotami rynku finansowego.

Funkcjonowanie FOS jako ustawowego alternatywnego mechanizmu rozstrzygania sporów konsumenckich na rynku finansowym z wiążącym charakterem orzeczeń rzeczników, pozwala na eliminowanie nadużyć wobec konsumentów, skuteczne zapobieganie i zarządzanie ryzykiem braku zgodności oraz kształtowanie prawidłowych praktyk rynkowych na tym rynku, zapewniając jego stabilne funkcjonowanie. Odpowiednie zasady jego finansowania stymuluja i promuja wewnętrzny proces reklamacyjny oraz rozpatrywanie skarg klientów z należyta powagą, starannością i w satysfakcjonujący obie strony sposób przez same instytucje finansowe. Wydaje się, że jest to system, który pozwala instytucjom finansowym na rzeczywiste kształtowanie wizerunku instytucji społecznie odpowiedzialnej i etycznej z dobrze funkcjonującym wewnętrznym mechanizmem samodyscypliny rynkowej, co jest niezwykle istotne dla prawidłowego funkcjonowania rynku finansowego. Pozwala kształtować pożądane praktyki rynkowe instytucji finansowych w relacjach z konsumentami i eliminować nieprawidłowości w tym obszarze oraz ryzyko braku zgodności ${ }^{86}$. Skuteczne i szybkie, a przy tym profesjonalne rozpatrywanie sporów na rynku finansowym jest szczególnie istotne w rzeczywistości pokryzysowej, gdzie skala tych nadużyć wzrosła, a skutki tego stanu moga generować nawet ryzyko systemowe na rynku finansowym ${ }^{87}$. Stąd też zarządzanie ryzykiem braku zgodności w obszarze prawa ochrony konsumenta usług finansowych na różnych poziomach - przez samą instytucję finansową, w której powinny funkcjonować odpowiednie komórki wewnętrzne odpowiedzialne za wykonywanie tego zadania, także w kontekście rozpatrywania skarg (reklamacji) konsumentów, ale również przez właściwe organy nadzoru mikro- i makroostrożnościowego, stało się obecnie kwestią nie tyle istotną, ile priorytetową.

85. Rządowy projekt ustawy o rozpatrywaniu reklamacji i sporów klientów podmiotów rynku finansowego oraz o Funduszu Edukacji Finansowej (Druk nr 834) - sejm.gov.pl. Na posiedzeniu Sejmu RP 21 stycznia w głosowaniu odrzucono projekt ustawy w I czytaniu. Wcześniejsza wersja - projekt ustawy o rozpatrywaniu reklamacji i sporów klientów podmiotów rynku finansowego oraz o Funduszu Edukacji Finansowej (UD125) (RM-10-80-20) Projekt (rcl.gov.pl).

86. Szerzej: E. Rutkowska-Tomaszewska, Aktualne trendy i wyzwania w zakresie ochrony konsumenta na rynku finansowym : dokqd zmierza (powinna zmierzać] ochrona konsumenta?: kilka wybranych uwag, [w:] Ekonomia jako dyscyplina naukowa i kierunek kształcenia : aktualne trendy i pożqdane zmiany, [red.] E. Rutkowska-Tomaszewska, W. Kwaśnicki, Difin, Warszawa 2020, s. 254-288.

87. Por. także E. Rutkowska-Tomaszewska, Misselling i inne nadużycia instytucji finansowych wobec konsumentów na rynku usług finansowych, [w: Manipulacje i oszustwa na rynku finansowym: perspektywa konsumenta, wykrywanie, przeciwdziałanie, zapobieganie, [red.] A. Jurkowska-Zeidler, E. Rutkowska-Tomaszewska, A. Wiktorow, J. Monkiewicz, Wydawnictwo Naukowe PWN, Warszawa 2020, s. 5 ? 


\section{Wykaz źródeł}

\section{Literatura:}

Ali S.F., Da Roza A., Alternative dispute resolution design in financial markets - some more equal than others: Hong Kong's proposed financial dispute resolution center in the context of the experience in the United Kingdom, United States, Australia, and Singapore, "Pacific Rim Law \& Policy Journal" 2012, Vol. 21, No. 3.

Ardic 0.P., Ibrahim J., Mylenko N., Consumer protection laws and regulations in deposit and loan services: A cross-country analysis with a new data set, "World Bank Policy Research Working Paper" 2011, No. 5536.

Bombin M., Methods Used in Evaluating The Ombudsman Function of an International Organization, "JIOA" 2014, Vol. ?.

Bradford B., Creutzfeldt N. Procedural justice in Alternative Dispute Resolution: Fairness judgments among users of Financial Ombudsman services in Germany and the United Kingdom. "Journal of European Consumer and Market Law" 2018, No. ? (5).

Czechowska I.D., Stawska J., Witczak R., Bezpieczeństwo i stabilność systemu finansowego. Perspektywa makro- i mikroekonomiczna, Wydawnictwo Uniwersytetu Łódzkiego, Łódź 2020.

Gajda-Roszczynialska K., Sprawy o ochronę indywidualnych interesów konsumentów w postępowaniu cywilnym, Wolters Kluwer, Warszawa 2011.

Gilad S., Accountability or expectations management? The role of the ombudsman in financial regulation, "Law \& Policy" 2008, No. 30[2].

Gilad S., Exchange without capture: The UK financial ombudsman service's struggle for accepted domain, "Public Administration" 2008, No. 86(4), https://doi.org/10.1111/j.146? 9299.2008.00713.x [dostęp: 30.07.2021].

Huijuan X., On Financial Ombudsman System in UK and Protection of Consumers' Rights and Interests - comment on our financial regulations [J], "Finance Forum" 2015, Vol. 1.

Kalak J., Pozasqdowe postępowanie w sprawie rozwiqzywania sporów między klientem a podmiotem rynku finansowego, „ADR” 2016, $\mathrm{nr} 2$.

Lloyd R., Report of the Independent Review of the Financial Ombudsman Service, 2018.

MacNeil I., Consumer dispute resolution in the UK financial sector: the experience of the Financial Ombudsman Service Pages, https://doi.org/10.1080/17521440.2007.11427928 [dostęp: 3.09.2021].

Magoń K., Ochrona klienta usług finansowych w świetle ustawy o rozpatrywaniu reklamacji przez podmioty rynku finansowego i o Rzeczniku Finansowym - zagadnienia wybrane, [w: ] Ochrona klienta na rynku usług finansowych w świetle aktualnych problemów i regulacji prawnych, Rutkowska-Tomaszewska, E. [red.], CH Beck, Warszawa 2017.

Mucha J., Alternatywne metody rozwiqzywania sporów konsumenckich w Unii Europejskiej, CH Beck, Warszawa 2020.

Pisarewicz P., Analiza złych praktyk brytyjskich instytucji finansowych - wnioski dla rynku polskiego, „Zarządzanie i Finanse” 2014, nr 2.

Rutkowska-Tomaszewska E., Prawo ochrony konsumenta usług finansowych w świetle założenia racjonalnego ustawodawcy: kilka wybranych uwag, „Acta Universitatis Wratislaviensis. Przegląd Prawa i Administracji” 2020, nr 120/2. 
Rutkowska-Tomaszewska E., Czy struktura instytucjonalna ochrony konsumenta na rynku usług finansowych wymaga zmian?, „Przeglad Ustawodawstwa Gospodarczego” 2019, nr 11.

Rutkowska-Tomaszewska E., Misselling i inne nadużycia instytucji finansowych wobec konsumentów na rynku usług finansowych, [w:] Manipulacje i oszustwa na rynku finansowym: perspektywa konsumenta, wykrywanie, przeciwdziałanie, zapobieganie, Jurkowska-Zeidler A., RutkowskaTomaszewska E., Wiktorow A., Monkiewicz J. [red.], PWN, Warszawa 2020.

Rutkowska-Tomaszewska E., Zaufanie do rynku finansowego i instytucji finansowych jako przedmiot ochrony prawnej (kilka uwag na tle nadużyć instytucji finansowych wobec klientów), „Przedsiębiorczość i Zarządzanie” 2018, t. XIX, z. 9, cz. II.

Rutkowska-Tomaszewska E., Current trends in consumer protection regulations in the financial services market in Poland, [w: Consumer rights protection: threats and opportunities for enhancing consumer awareness, Smyczek S. [red.], Uniwersytet Ekonomiczny w Katowicach, Katowice 2020.

Szymański Ł. Organizacja i działanie Financial Ombudsman Service w Wielkiej Brytanii, „Rozprawy Ubezpieczeniowe" 2008, nr 2[5].

Tereszkiewicz P., Obowiqzek informacyjny ubezpieczajqcego i skutki jego naruszenia z perspektywy prawno-porównawczej: zmierzch uberrima fidei w epoce ochrony konsumenta?, [w:] Rozprawy cywilistyczne. Księga pamiq̨tkowa dedykowana Profesorowi Edwardowi Drozdowi, Pecyna M., Pisuliński J., Podrecka M. [red.], LexisNexis, Warszawa 2013.

Więcko-Tułowiecka M., Ochrona konsumentów w umowach ubezpieczenia, LexisNexis, Warszawa 2014.

\section{Strony internetowe:}

annual-complaints-data-2019-20-exel [dostęp: 3.09.2021].

annual-complaints-data-2020-21-exel [dostęp: 3.09.2021].

Department for Business, Energy \& Industrial Strategy, Resolving Consumer Disputes Alternative

Dispute Resolution and the Court System Final Report, April 2018. https://assets.publishing. service.gov.uk/government/uploads/system/uploads/attachment_data/file/698442/Final_report - Resolving_consumer_disputes.pdf [dostęp: 21.07.2021].

FEES 5 Annex 3R Case Fees Payable for 2020/21 [dostęp: 21.07.2021].

Fees Manual Chapter 5. Financial Ombudsman Service Funding Fees Manual 38 s. pdf [dostęp: 30.06.2021].

Financial Ombudsman Service, Laying The Foundations: First Annual Report 1999-2000 (2000), http://www.financial-ombudsman.org.uk/publications/first-annual-report/ar-1999- 2000.pdf [dostęp: 21.07.2021].

Financial Ombudsman Service. Annual review 2017/2018, Fairnessin a changing world. https:// www.financial-ombudsman.org.uk/files/2022/Annualreview-fullreport-AR2016-17.pdf [dostęp: 30.06.2021].

Financial Ombudsman Service. Annual review 2018/2019. Data in more depth. [dostęp: 21.07.2021]. Financial Ombudsman Service. Annual review 2018/2019, https://www.financial-ombudsman. org.uk/who-we-are/governance-funding/annual-reports-accounts/annual-review [dostęp: 21.07.2021]. 
Funkcjonowanie systemu ochrony praw klientów podmiotów rynku finansowego, Najwyższa Izba Kontroli, Warszawa 2014 r., Informacja o wynikach kontroli a P/13/038, https://www.nik.gov. pl/plik/id,6423,vp,8193.pdf [dostęp: 31.08.2021].

Global Survey on Consumer Protection and Financial Literacy: Oversight Frameworks and Practices in 114 countries. Report. Washington DC: The World Bank, 2014 [dostęp: 21.07.2021].

Komunikat Komisji do Parlamentu Europejskiego, Rady, Komitetu Ekonomiczno-Społecznego i Komitetu Regionów „Europejski program na rzecz konsumentów - wzmacnianie zaufania i wzrostu” COM/2012/0225 final (https://eur-lex.europa.eu/legal-content/EN/TXT/?uri=COM:2012:0225:FIN) [dostęp: 21.07.2021].

Komunikat Komisji do Parlamentu Europejskiego i Rady „Nowy program na rzecz konsumentów Poprawa odporności konsumentów na potrzeby trwałej odbudowy", Bruksela, dnia 13.11.2020 r. COM(2020) 696 final, https://eur-lex.europa.eu/legal-content/PL/TXT/PDF/?uri=CELEX:520 20DC06968from=PL [dostęp: 21.07.2021].

Komunikat Komisji do Parlamentu Europejskiego, Rady i Europejskiego Komitetu Ekonomiczno-

Społecznego Nowy Ład dla Konsumentów z dnia 11 kwietnia 2018 r., COM(2018)183 final), https://eur-lex.europa.eu/legal-content/pl/ALL/?uri=COM\%3A2018\%3A0183\%3AFIN [dostęp: 21.07.2021].

http://documents1.worldbank.org/curated/en/301411468261335666/pdf/699160v20ESWOPOI

00mbudsmenOVol20ECA.pdf [dostęp: 21.07.2021].

http://www.financial-ombudsman.org.uk (25.07.2021] [dostęp: 21.07.2021].

https://doi.org/10.5235/108546810793129358; Collective Forms of Consumer Redress: Financial

Ombudsman Service Case Study, Vicki Waye, Vince Morabito, s. 1-31, 7 May 2015, Download citation https://doi.org/10.5235/147359712800129902 [dostęp: 21.07.2021].

https://www.fca.org.uk/firms/authorisation/how-to-apply/activities [dostęp: 21.07.2021]. https://www.fca.org.uk/firms/calculate-your-annual-fee/fee-calculator [dostęp: 21.07.2021]. https://www.fca.org.uk/firms/fees [dostęp: 25.07.2021]. https://www.financial-ombudsman.org.uk/consumers/expect/compensation [dostęp: 30.06.2021]. https://www.financial-ombudsman.org.uk/consumers/expect/who-we-can-help [dostęp: 25.07.2021]. https://www.financial-ombudsman.org.uk/consumers/how-to-complain [dostęp: 27.07.2021]. https://www.financial-ombudsman.org.uk/decisions-case-studies/ombudsman-decisions [dostęp: 27.07.2021].

https://www.financial-ombudsman.org.uk/files/1953/ADR-activity-report-2015-16.pdf [dostęp: 30.06.2021].

https://www.financial-ombudsman.org.uk/files/1954/ADR-activity-report-2016-17.pdf [dostęp: 30.06.2021].

https://www.financial-ombudsman.org.uk/files/1955/ADR-activity-report-2017-18.pdf [dostęp: 30.06.2021].

https://www.financial-ombudsman.org.uk/files/241933/ADR-activity-report-2018-19.pdf; [dostęp: 30.06.2021].

https://www.financial-ombudsman.org.uk/files/280886/ADR-activity-report-2019-20.pdf; [dostęp: 30.06.2021].

https://www.financial-ombudsman.org.uk/files/287580/Annual-Report-and-Accounts-for-the-yearended-31-March-2020.pdf [dostęp: 3.08.2021]. 
https://www.financial-ombudsman.org.uk/files/298949/plans-and-budget-2021-22.pdf [dostęp: 30.09.2021].

https://www.financial-ombudsman.org.uk/who-we-are/aims-values [dostęp: 25.07.2021]. https://www.financial-ombudsman.org.uk/who-we-are/governance-funding [dostęp: 30.07.2021]. https://www.financial-ombudsman.org.uk/who-we-are/staff/ombudsmen [dostęp: 19.08.2021]. Judicial Review of the Financial Ombudsman Service: Permission to Proceed and the Availability of an Alternative Remedy, Julian Davis, s. 63-266, http://www.hmcourts-service. gov.uk/ cms/1220.htm [dostęp: 30.06.2021].

Lloyd R., Report of the Independent Review of the Financial Ombudsman Service. file://C:/Users/ user/AppData/Local/Temp/independent-review-2018.PDF [dostęp: 30.06.2021].

Our 2021/22 plans and budget Consultation. December 2020. Financial Ombudsman Service. https:// www.financial-ombudsman.org.uk/files/290682/plans-and-budget-consultation-2021-22.pdf [dostęp: 30.06.2021].

Podręcznik organu nadzoru (FCA) dotyczący rozwiązywania sporów (FCA Handbook).Dispute resolution:Complaints, DISP-i www.handbook.fca.org.uk n Release 1 I Nov 2020 https://www. handbook.fca.org.uk/handbook/DISP/INTRO/?view=chapter [dostęp: 30.06.2021].

Projekt ustawy o rozpatrywaniu reklamacji i sporów klientów podmiotów rynku finansowego oraz o Funduszu Edukacji Finansowej (UD125) (RM-10-80-20), Projekt (rcl.gov.pl) [dostęp: 30.06.2021].

Rządowy projekt ustawy o rozpatrywaniu reklamacji i sporów klientów podmiotów rynku finansowego oraz o Funduszu Edukacji Finansowej (Druk nr 834) - sejm.gov.pl [dostęp: 3.09.2021].

The Case Fee, FINANCIAL OMBUDMAN SERVICE, http://www.financialombudsman.org.uk/faq/answers/research_a5.html [dostęp: 3.09.2021].

The role of the Financial Ombudsman Service in the UK redress landscape (prezentacja PDF) Caroline Wayman Principal Ombudsman and Legal Director Financial Ombudsman Service https://www. lawscot.org.uk/media/6424/ilg_financialombudsmen_slides.pdf [dostęp: 30.06.2021].

Thomas D., Frizon F., Resolving disputes between consumers and financial businesses: Fundamentals for a financial ombudsman. A practical guide based on experience in western Europe. World Bank. Global Program on Consumer Protection and Financial Literacy [dostęp: 20.07.2021].

World Bank, Good Practices for Financial Consumer Protection 2012, http://responsiblefinance.worldbank.org/ /media/ GIAWB/FL/Documents/Misc/Good-practices-for-financialconsumerprotection.pdf [dostęp: 20.07.2021]

World Bank, Global Financial Inclusion and Consumer Protection Survey. 2017 Report, https://openknowledge.worldbank.org/bitstream/handle/10986/28998/122058. pdf? sequence $=58$ cisAllowed=y [dostęp: 18.08.2021] .

Yokoi-Arai, M. A comparative analysis of the financial ombudsman systems in the UK and Japan. "Journal of International Banking Regulations" 2004, nr 5(4), https://doi.org/10.105?/palgrave.jbr.2340175 [dostęp: 20.07.2021]. 


\section{Financial Ombudsman in UK as an Effective Alternative Dispute Resolution System in the Financial Market - a Lesson for Poland?}

The institution of a financial ombudsman, especially after the crisis in the financial market, has become an indispensable entity to increase the level of consumers' trust in the financial services market and its protection bodies. The aim of the study is to present and evaluate the functioning of the Financial Ombudsman Services in the UK. British Financial Ombudsman is the largest such institution in the world, has been operating since 2001 and already has an established position in the system of customer protection bodies in the financial market in this country. The research question the authors are trying to answer is whether the FOS as an alternative dispute resolution system is effective and whether it can be a model for such institutions in other countries, especially in Poland. The aim of this system is to provide consumers with a statutory alternative dispute resolution (ADR) system whereby complaints against providers of financial services primarily by individual customers (consumers) can be resolved quickly and with a minimum of formalities in a binding manner by a professional and independent entity [ombudsman] in a fair and reasonable manner. The article uses the following research methods: analysis of legal acts, desk research and analysis of FOS statistical data.

Keywords: ADR, alternative dispute resolution, financial ombudsman, financial market.

PROF. UWR DR HAB. EDYTA RUTKOWSKA-TOMASZEWSKA - doktor hab. nauk prawnych, prof. Uniwersytetu Wrocławskiego, pracownik naukowo-dydaktyczny Wydziału Prawa, Administracji i Ekonomii Uniwersytetu Wrocławskiego. Kierownik Zakładu Zarządzania Finansami. Specjalizuje się w problematyce regulacji rynku finansowego, ze szczególnym uwzględnieniem prawa usług finansowych, a zwłaszcza ochrony klienta (konsumenta) na tym rynku. Autorka licznych publikacji oraz organizatorka konferencji z zakresu wskazanej problematyki badawczej.

ORCID: 0000-0001-9359-7034

e-mail: edyta.rutkowska-tomaszewska@uwr.edu.pl

PROF. UŁ DR HAB. IWONA DOROTA CZECHOWSKA - doktor hab. nauk ekonomicznych, prof. Uniwersytetu Łódzkiego, kierowniczka Katedry Bankowości Centralnej i Pośrednictwa Finansowego na Wydziale Ekonomiczno-Socjologicznym Uniwersytetu Łódzkiego. Specjalizuje się w problematyce finansów i bankowości, ze szczególnym uwzględnieniem ochrony klienta (konsumenta) na tym rynku. Autorka licznych publikacji oraz organizatorka konferencji z zakresu wskazanej problematyki badawczej.

ORCID: 0000-0002-8051-5324

e-mail: dorota.czechowska@uni.lodz.pl 